\title{
Jacek Stefański
}

Independent scholar

ORCID 0000-0002-1079-4778

\section{Medieval Karaite Exegesis as Evidenced in Selected Examples from Yefet Ben Eli's Commentary on the Book of Hosea ${ }^{1}$}

\begin{abstract}
For many years, Karaite exegesis was relatively unknown to numerous Biblical scholars. This situation has been changing with an increasing access to source materials. As a result, more and more Karaite exegetical treasures representing the trends of Karaite Judaism have come to the fore. Among them, there is the Commentary on the Book of Hosea by Yefet ben Eli, one of the most significant representatives of Karaism in the tenth century. This Karaite exegete exhibits a remarkable knowledge of Hebrew etymology, which enables him to provide unique answers to the interpretative problems in the Masoretic Text. His apologetic concern for prospective Muslim readers of his commentary is also noteworthy. Although, in general, Karaism sought to concentrate on the literal sense of Scripture, Yefet ben Eli does not shy away from recourses to rabbinic oral tradition. Nevertheless, his exegetical contribution remains unique, as clearly demonstrated by the selected examples from his Commentary.
\end{abstract}

Keywords: Karaism, Karaite Judaism, Masoretic Text, Hebrew, apologetics, literal interpretation, oral tradition, rabbinic exegesis

The encouragement extended by the Pontifical Biblical 1 Commission for Christian scholars to make use of Jewish exegesis has led to an increase in the amount of research on

\footnotetext{
${ }^{1}$ The present article is a corrected and supplemented version of the text originally published in Polish: Jacek Stefański, "Średniowieczna egzegeza karaimska na przykładzie wybranych zagadnień z komentarza Jefeta Ben Eliego do Księgi Ozeasza," Collectanea Theologica 86 (2017) no. 4, 205-222.
} 
the centuries-old Jewish Biblical interpretative tradition. ${ }^{2}$ In spite of that, even today there continues to be a gap in these studies due to the still relatively unknown field of Biblical interpretation which originated in the Jewish Karaite circles. Over the centuries, the lack of access to Karaite source materials may have resulted in the significantly limited academic interest in Karaite exegesis. Besides, the Arab environment in which the medieval Karaites found themselves, could have led to an aversion and a slightly disdainful attitude toward Jewish exegetical works composed within Karaite communities surrounded by a Muslim population. An additional factor is the ignorance of Arabic and Judeo-Arabic dialects used by Karaite exegetes, which - in turn-was the reason why scholars resorted to translations from Arabic, especially into English. ${ }^{3}$

This study presents a selection of themes from the Karaite commentary on the Book of Hosea, written by one of the most distinguished medieval Karaites, Yefet ben Eli. The individual examples from this commentary which are discussed here demonstrate the principles that guided Karaites in their biblical commentaries. One can infer from them that Karaite Judaism combined exegesis with an apologetic intent in order to acquaint Muslim readers with the Hebrew Bible.

\footnotetext{
${ }^{2}$ Cf. Pontifical Biblical Commission, The Interpretation of the Bible in the Church, April 23, 1993, I C 2.

3 The first significant academic project - which resulted in a critical edition of Karaite works - was undertaken at the University of Cambridge as late as in 2000. More on that, see G. Khan, "The Early Karaite Tradition of Hebrew Grammatical Thought. Including a Critical Edition, Translation and Analysis of the Diqduq of "Abu Ya'qub Yusuf ibn Nuh on the Hagiographa I," in: T. Muraoka, C.H.M. Versteegh, eds., Studies in Semitic Languages and Linguistics, vol. XXXII, Leiden 2000. In addition, the most exhaustive survey of research works in the filed of Karaite exegesis was published in 2011; see B.D. Walfish, M. Kizilov, "Bibliographia Karaitica. An Annonated Bibliography of Karaites and Karaism," in: M. Polliack, M.G. Wechsler, eds., Karaite Texts and Studies, vol. 2, Leiden 2011.
} 


\section{Karaite Judaism}

There are various theories on the origin of the Karaite movement, which historians attempt to incorporate and combine into a whole. ${ }^{4}$ It is assumed that in the second half of the eighth century, among Arab Jews living in places, where Islam had already been profoundly rooted, there was a debate between the heads of rabbinical schoolsgeonim - and the leaders of the Jewish communities in the diaspora, referred to as rashei galut. The debate stemmed from the fact that the geonim represented the Jewish intelligentsia, drawing its authority most of all from their familiarity with - and dissemination of - the Jewish oral tradition, as recorded in the Mishnah and Talmud. As opposed to the geonim, the rashei galut enjoyed the recognition of 'am ha'aretz, that is, the common Jews who were unfamiliar with rabbinic tradition. Therefore, some of the rashei galut would reject the oral tradition transmitted by the Mishnah and Talmud, demanding that Jews strictly abide by the Hebrew Bible. That way, the Karaite movement was established as a faction of "readers", because the word karaim is derived from the root kara or likro - "to read." Accordingly, Karites became those who considered themselves to be the true "readers" and "listeners" of the word of God-mikra - and its faithful adherents, as opposed to those who yielded to Jewish oral tradition. In that respect, the Karaite movement became a sort of "Jewish protestantism," rejecting the oral tradition in favor of the Bible. For that reason, Karaites held the belief that if they were the only ones who followed strictly the word of God (as conveyed by the Hebrew Bible), then this must have meant that they constituted the orthodox portion of Israel. ${ }^{5}$ The same self-appraisal can be noted in the expression bnei

\footnotetext{
4 Cf. D.J. Lasker et al., "Karaites," in: M. Berenbaum, F. Skolnik, eds., Encyclopaedia Judaica, vol. 11, Detroit 2007, 786-9; G. Khan, The Early Karaite Tradition of Hebrew Grammatical Thought, 1-2.

${ }^{5}$ One should note that the Hebrew root kara not only means "to read," but also "to call." This fact proves significant in light of the role of the muezzin (literally: "the one who listens") in the Muslim mosque. For when the muezzin calls Muslims to gather for prayer, he simultaneously places his hand next to his ear to indicate that his call to prayer originates in what he himself can hear from the Creator. The same
} 
mikra ("the sons of the [holy] Scripture"), which was used by Karaites as an identifying self-description.

It is believed today that the first Karaites drew their inspiration from the Sadducee movement. ${ }^{6}$ However, the most distinguished figure associated with the rejection of the Jewish oral tradition was Anan ben David, a sage from the house of David who lived in the eighth century. $\mathrm{He}$ is first mentioned in Karaite sources from the tenth century. ${ }^{7}$ His conflict with the rabbinic authorities resulted in his imprisonment. However, he was able to persuade the local caliph that neither him, nor his followers, could be considered Jews by Muslims, due to the fact that they had rejected rabbinic oral tradition. As a result, the caliph freed Anan ben David, who then settled in Baghdad. ${ }^{8}$ His public rejection of rabbinic authority in the presence of the Muslim community secured a more moderate treatment of him and his followers by the Muslim community.

This episode from the life of Anan ben David would be reflected in the subsequent history of the Karaite movement, because over the centuries in many areas where the Jewish community was oppressed, Karaites would invoke their distinctive identity in opposition to the rest of the Jews and would thus able to secure favorable treatment by the local Muslim authorities. This tactic was undoubtedly instrumental in facilitating the Karaite's survival in many places where other Jews could not count on benevolent treatment. ${ }^{9}$

The rejection of the oral tradition in favor of close interpretation of the Masoretic Text made Anan ben David and his successors proponents of an effort to improve the knowledge of Hebrew grammar in order to better elucidate particular words and

connotation is present in the term karaim ("Karaites"), and karai ("Karaite"), due to the Karaite assertion that their reading of the Bible leads Karaites to conclusions inspirited by God, drawn directly from the Biblical text which is read and listened to, and not from oral tradition. Cf. D.J. Lasker et al., Karaites, 785.

${ }^{6}$ Cf. D. Frank, "Search Scripture Well. Karaite Exegesis and the Origins of the Jewish Bible Commentary in the Islamic East," in: P.B. Fenton, ed., Etudes sur Le Judaisme Medieval, vol. 29, Leiden 2004, 1.

7 Cf. L. Nemoy, "Anan ben David," in: M. Berenbaum, F. Skolnik, eds., Encyclopaedia Judaica, vol. 2, 127.

${ }^{8}$ Cf. ibid.

${ }^{9}$ Today, Orthodox Judaism does not regard Karaites as authentic Jews. 
expressions in the Hebrew Bible. Admittedly, rabbinic exegesis is also based on extensive knowledge of the Hebrew grammar; however, the Karaite exegetical method strives to begin the explanation of a word or a phrase in a given verse by demonstrating its relation to adjacent words or phrases. ${ }^{10}$ In that regard, any references to midrashic images are rare in the Karaite exegesis.

\section{Yefet ben Eli-A Representative of Medieval Karaism}

One of the most distinguished representatives of medieval Karaism was Yefet ben Eli (in Arabic, Abu Ali Hasan Ibn Ali Albasri). Born in in the first half of the tenth century, he most likely came from the city of Basra in south-east Iraq, in the vicinity of the Persian Gulf. Between 950 and 980, he moved to Jerusalem, where he became well-known in the Karaite community for his Biblical knowledge. He was the first Jewish exegete to write a commentary on the entire Hebrew Bible. ${ }^{11}$ He spent the last four decades of his life translating the Scriptures and commenting on them. He also composed a halachic work entitled Sefer ha-Mitsvot ("The Book of Precepts"). He enjoyed great recognition among Karaite exegetes in the Middle Ages, while his commentaries were cited and elaborated on by Jewish rabbinic commentators, especially the twelfth century Spanish exegete Abraham ibn Ezra. ${ }^{12}$ Yefet ben Eli

${ }^{10}$ M. Goldstein, "The Beginning of the Transition from «Derasz» to «Peshat» as Exemplified in Yefet ben 'Eli's Comment on Psa. 44:24,” in: G. Khan, Exegesis and Grammar in Medieval Karaite Texts, Journal of Semitic Studies Supplement 13, Oxford 2001, 41.

${ }^{11}$ Cf. K. Almbladh, "MS Uppsala O Nova 791 - a rediscovered manuscript of the Arabic translation of and commentary on the Song of Songs by Yapheth ben Eli," Orientalia suecana LXI, Suppl. (2012): 33. On the research into the activity of Yefet ben Eli, see M. Zawanowska, "Review of Scholarly Research on Yefet Ben Eli and His Works," Revue des Etudes Juives 173, nos. 1-2 (2014): 97-138.

${ }^{12}$ Cf. M. Polliack, E. Schlossberg, "Historical-literary, Rhethorical and Redactional Methods of Interpretation in Yefet ben 'Eli's Introduction to the Minor Prophets," in: G. Kahn, Exegesis and Grammar in Medieval Karaite Texts, 4; M. Polliack, "The Karaite Tradition of Arabic Bible Translation. A Linguistic and Exegetical Study of Karaite Translations of the Pentateuch from the Tenth and Eleventh Centuries C.E.," in: P.B. Fenton, E.R. Wolfson, eds., Etudes sur Le Judaisme Médiéval, vol. 17, Leiden 1997, 17. 
died in Jerusalem towards the end of the tenth century, at a time when the Karaite movement was at its spiritual and academic bloom.

\section{Yefet ben Eli's Commentary on the Book of Hosea}

\section{General characteristics}

Yefet ben Eli believed that the prophetic books contain a relevant message for all the future generations of Israel. Whereas mainstream Karite exegesis searched the Scriptures for a message concerning the role of the Karaites in God's plans, Yefet searched the Masoretic Text for a message intended not only for the narrow Karaite community, but also for all Jews. With his emphasis on the didactic and spiritual aspect of the prophetic books, Yefet's thought comes close to that of rabbinic commentators, although - much like other Karaites-he recognizes the prophetic books as an instrument of acquiring knowledge about the future.

Considering the fact that the Book of Hosea is the first within the Twelve Minor Prophets collection, Yefet concluded that it must be seen as an introduction to the prophetic theme in general. That is why he provides an extensive introduction to his Commentary on the Book of Hosea, where he lists the reasons why God sent his prophets and indicates the goals that were to be achieved by the reading of the prophetic books. ${ }^{13}$

Yefet ben Eli's Commentary on Hosea was written in Arabic, but using Hebrew letters. Among the Arabic words, there also appear some strictly Hebrew ones, as well as Hebrew words in an Arabic dialect. The commentary opens with the passage: "Blessed be the God of Israel, the One, the Ancient, Who is, the Eternal One without end, the Creator, who leads His world at every moment . . ."14 It is worth noting that these words of praise are written in a style reminiscent of the expressions of praise in the Quran: "In the

\footnotetext{
${ }^{13}$ See M. Polliack, E. Schlossberg, eds., Yefet ben 'Eli's Commentary on Hosea. Annotated Edition, Hebrew Translation and Introduction, Ramat Gan 2009, 259-61. The work edited by M. Polliack and E. Schlossberg is the most recent critical Hebrew edition of Yefet ben Eli's Commentary on the Book of Hosea. It served as the primary source for this paper.

${ }^{14}$ Ibid., 259.
} 
name of God, the Lord of Mercy! Praise belongs to God, Lord of the Worlds, the Lord of Mercy, the Giver of Mercy, Master of the Day of Judgment."15

This stylistic similarity to the Quran is far from accidental, for in the very same introduction to the Book of Hosea, after the Israelites' words of praise (based on Psalm 135:4), when Yefet discusses the reason why God selected and sent his prophets, he also alludes to the figure of Moses. Moses is not mentioned by name, but he referred to by the Arabic title of al rasul, that is, "the messenger."16 This term is significant, because the same word (rasul) is used in the Quran to refer to Muhammad and to the Old testament prophets. Hence, it can be said that Yefet is in line with Karaite exegesis, since the distinctive feature of the latter is its use of Muslim terminology. Karaite exegesis also utilized literary instruments used by Muslim scholars not only in their religious works, but in philosophical studies as well. ${ }^{17}$

Yefet's use of Muslim terminology did not stem solely from the fact that Jews in Mesopotamia were in constant contact with Arabs. Particularly in the case of Yefet, who wrote his entire Commentary on the Hebrew Bible in Arabic, his use of Muslim terminology may have resulted from an awareness that his works would be read not only by Jews, but also - out of sheer curiosity-by Muslims. In other words, it is highly probable that in the person of Yefet ben Eli we are dealing with a Karaite exegete who was driven by an apologetic intent. ${ }^{18}$

After the introduction to his work on Hosea, Yefet goes on to provide a commentary to every verse, one at a time. He proceeds according to a fixed procedure, namely he first provides his own Arabic translation of the Masoretic Text, and next proceeds to furnish a commentary on it. Yefet's Arabic translation is given directly without the Hebrew version of the Masoretic Text. It is only in the Arabic commentary that Yefet focuses on the respective

15 The Opening [Al Fatihah], 1:1-4, in: The Qur'an, A New Translation, M.A.S. Abdel Haleem, Oxford, UK 2005, 3.

${ }^{16}$ M. Polliack, E. Schlossberg, Yefet ben 'Eli's Commentary on Hosea, 259.

${ }^{17}$ Cf. D. Frank, Search Scripture Well, 257.

${ }^{18}$ Cf. M. Polliack, The Karaite Tradition of Arabic Bible Translation, 3. 
Hebrew words and expressions from the Masoretic Text, not omitting a single one of those. He also explains pertinent grammar issues where he sees fit.

At the end of his Commentary on the Book of Hosea, Yefet compiles a list of difficult Hebrew words in the Masoretic Text, and provides their morphology, while referring to various locations in the Hebrew Bible, where these words are used. Admittedly, this list is far from exhaustive, nor does it provide any new pieces of information which are not given in the Commentary. It merely serves as a kind of a summary of Yefet's work, which enables the reader to gain quick insight into selected issues and check some general information from the translation and the Commentary.

\section{Selected Examples from the Commentary}

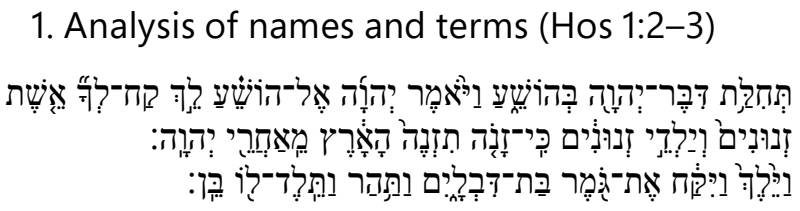

"The beginning of the word of the Lord to Hosea. And the Lord said to Hosea: Go, take for yourself a wife of harlotry [eshet znunim] and children of harlotry [yaldey znunim], because committing harlotry, the land prostituted itself away from the Lord. And he went and took Gomer-bat-Divlaim, and she conceived and bore him a son." 19

Yefet's translation from Hebrew to Arabic is as follows:

"The beginning of the discourse of God to Hosea; He said to him: Go, take for yourself an idol worshipping wife and she will bear you idol worshipping children, for the land will turn away from worshipping the Lord. And he went and took a wife whose name was whole, the daughter of two halves, and she conceived and bore him a son."

${ }^{19}$ All translations from the Hebrew Masoretic Text were made by the author of this article. 
A. The translation of the term eshet znunim ("a wife of harlotry") as accommodated with regard to the reader and an allegoric interpretation on the basis of redundant words in the statement ki zano tizne haarets maacharey adonaj (". . . because committing harlotry, the land prostituted itself from the Lord") (Hos 1:2).

Considering the emphasis placed by Karaite exegesis on literal fidelity to the Masoretic Text, the above Arabic translation by Yefet may seem rather perplexing. For Yefet does not provide a literal translation from Hebrew, but includes his own interpretation in this very rendering, even before proceeding to provide a commentary on the above verses (Hos 1:2-3). It is only in his commentary that Yefet provides a literal translation of the words of the Masoretic Text and adds that the description refers to a harlot and to children of harlotry. Why should there be a discrepancy between Yefet's imprecise translation of the Masoretic Text, and his commentary on that text? It is here that we find a confirmation of the hypothesis that Yefet believed Muslims would read his Arabic translation of the Masoretic Text of Hosea. While being aware of the great significance attached by Muslims to the office of a prophet, Yefet did not wish to scandalize his Muslim readers at the very outset with God's command directed to a prophet that he must marry a prostitute. Only in the commentary on the verses which he translated from Arabic, Yefet, for the first time, refers to the literary meaning of the Hebrew phrases eshet znunim ("a wife of harlotry"), and yaldey znunim ("children of harlotry").

What Yefet suggests is that when God addressed Hosea with a command to marry a harlot, the directive did not refer to a physical woman, but to the nation of Israel. In order to substantiate this interpretation, Yefet points out that the second verse ends in words which should not normally be placed there: "Go, take for yourself a wife of harlotry [eshet znunim], and children of harlotry [yaldey znunim], because committing harlotry, the land prostituted itself away from the Lord." Yefet writes that the words "away from the Lord" are redundant, and would not have been placed there if the actual meaning had been that of contracting an actual marriage with a harlot, even if the harlot was to simultaneously symbolize the people of Israel. Yefet explains that since the words "away from 
the Lord" appear here nevertheless, it means that God's dictate to Hosea did not refer to the contraction of marriage, but to the situation in which Hosea found himself as a prophet observing the wretched moral state of his people.

B. The interpretation of the name Gomer bat divlaim in reference to the moral state of the people of Israel and in light of the meaning of each term (Hos 1:3).

Commenting on the name Gomer bat divlaim, Yefet begins with the word Gomer. He cites the root gamar, which refers to a completion or a fullness of something. Therefore, according to Yefet, the name Gomer may indicate "fullness," i.e. a maximum number of moral transgressions of the people of Israel due to their dissent from the rightful worship of God and His commands. It means that in moral terms Israel hit the rock bottom. Next, in his analysis of the term divlaim, Yefet is aware of the problem that the word is nowhere to be found in the Hebrew Bible. He suggests a possible interpretation of the word, by pointing at its relation to the term dvela, as in $1 \mathrm{Sam} 30: 12$, where one finds the expression pelakh vela - "a piece of fig cake," or a similar one in $2 \mathrm{Kgs}$ 20:7, where the phrase dvelet teenim, i.e., "a fig cake," is used. Yefet writes that on this basis, one can draw the conclusion the bat divlaim simply means the daughter of "two halves." How should we understand it? He suggests that these two halves of a fig cake are a visual reference to Moses and Aaron, who originated from one father and one mother. It is Moses and Aaron - as Yefet adds - who were a father and a mother for Israel, since Moses himself did wonder "Did I give birth to them [Israel]?" (Num 11:12).

C. The interpretation of the name Jezreel on the basis of an innovative etymological analysis (Hos 1:4).

Referring to Gomer's conception (Hos 1:4) of her first son, Jezreel, Yefet explains that the interpretation of this information must be metaphoric. Therefore, Jezreel, according to Yefet, represents every generation up to Jehu ben $\mathrm{Nimshi}^{20}$ that originated

\footnotetext{
${ }^{20} \mathrm{He}$ was the king responsible for the destruction of the house of Ahab and the execution of the prophets of Baal.
} 
from King Jeroboam II and his subjects who were raised as idol worshipers. However, what is significant here is Yefet's manner of interpreting Jezreel's name. Rabbinic tradition recognizes it as a term coined of two words, namely the verb zara - "to sow," and the word el-"God," which, together, make up the expression "God will sow" - izra el, or, in its onomastic form - Jezreel. ${ }^{21}$ Yefet admits that the name Jezreel contains the root zara-"to sow"; however, in the final two letters of Jezreel's name (alef and lamed) instead of what one may expect to be a reference to God $(e l)$, Yefet perceives something else: the negating term al. Such an interpretation is not without grounds, because the two final letters of the name Jezreel (alef and lamed) in the Masoretic Text were not furnished with Masoretic signs. Accordingly, it can be assumed that what we are dealing with here is not the Lord $(e l)$ who will sow (izra), but rather a negation of the very act of sowing (al izra). Thus, it is a conclusion opposite to the one reached by rabbinic tradition. Therefore, the lack of sowing indicates the lack of God's blessing for the descendants of Jeroboam and those among the Israelites who will turn to paganism.

2. From symbolism to moral attitude (Hos 1:6)

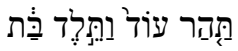

"And she conceived again and bore a daughter."

Yefet explains that whereas the symbolic sons born of the symbolic harlot, Gomer, refer to strong descendants (though unfaithful to God), the symbolic daughters born of symbolic Gomer refer to weak descendants. This way, the sex of the child becomes an allegory of a strong and stable proper moral attitude.

${ }^{21}$ See Y. Kiel, "Sefer Hoshea," in: A. Mirski et al., eds., Trey Asar, vol. 2: DaatMikra, Jerusalem 1990, 4-5. 


\section{Theological solution at the cost of literal interpretation (Hos 1:7)

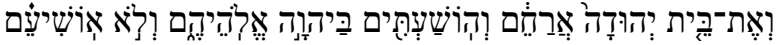

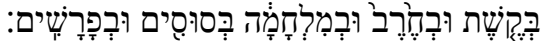

„And I will have mercy on the house of Judah, and I will save them by the Lord their God, and I will not save them by bow, nor by sword, nor by war, by horses, nor by horsemen."

Yefet's translation into Arabic is as follows:

"I will have mercy on the house of Judah and I will save them in the name of the Lord their God, and I will not save them by bow, nor by sword, nor by any instruments of war, nor by horses, nor by horsemen."

From the above translation into Arabic we can infer that Yefet performs here an unusual exegetic maneuver. For in the Masoretic Text, there is a pair of words uttered by God, the literal meaning of

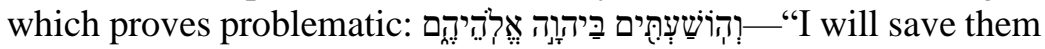
by God their Lord." The problem is that, if God is saying about himself that He will save Israelites by God their Lord, one might get the impression that there are in fact two Gods: the first one, addressing His words to Hosea ("I will have mercy on the house of Judah, and I will save them"), and the other one, whom God will use in order to save the people ("by the Lord their God"), although this second entity is also referred to as "Lord" and "God" by God himself. Such is the literal meaning of these words which seem to indicate two divine Persons. As a Karaite, Yefet was bound to notice this "peculiarity", for according to the Karite exegetic tradition one must primarily consider the literal meaning of the Masoretic Text. Due to the fact that, as a Jew, Yefet does not recognize the mystery of the Trinity, he is left with the single possible conclusion possible (from a Jewish perspective) that the interpretation of this passage cannot be literal. Consequently, in his translation of the verse he adds the Arabic word bism, that is "in the name of," which leads to the following translation: "I will save them in the name of the 
Lord their God." This means that God will save his people because of His name, as it is invoked by the sons of Israel.

4. Interpretation based on historical motifs (Hos 2:2)

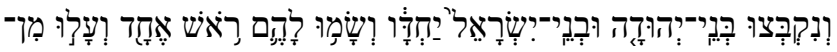

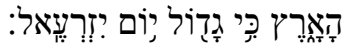

"And the sons of Judah and the sons of Israel will gather together and will establish one head for themselves and will go up from the land, for great shall be the day of Jezreel."

Yefet focuses on details which are not problematic in themselves. However, in his view, every detail — be it the most minute - is of great significance. This can be observed in the above passage (Hos 2:2), which Yefet renders in Arabic in the following way:

"The sons of Israel and the sons of Judah will gather together and will establish one head, and will go up from the land, before the day of Jezreel's salvation is great."

The significant element here is the reversal of the word order by Yefet, when he writes about the sons of Israel, and the sons of Judah. The Masoretic Text has the sons of Judah first, and then the sons of Israel. In his translation to Arabic, Yefet reverses this sequence without giving any reasons for it. However, he provides another rather particular idea, when he points out that whenever the names of Israel and Judah are used together, it is Israel that is chronologically first, due to the fact that it had been expelled first (by the Assyrians), whereas Judah is first in terms of suffering, for it was the descendants of Judah who suffered most because of the destruction of the First and the Second Temple in Jerusalem. In these words, Yefet-unawares - refers to the Messiah whose origins are not only in the house of David, but also in the tribe of Judah. In reality, from a Christian perspective, the destruction of the First and Second Temple thus becomes a distant reference to the Passion of Jesus. 
Yefet also suggests several possibilities as to the identity of the "head" mentioned in Hos 2:2. In the first place, Yefet names Elijah, ${ }^{22}$ as a second possibility, he points to an unidentified sage in a general sense and as a third possibility he suggests that it is the Messiah, as the one who will unite all the tribes of Israel and Judah.

5. Interpretation of the verb כרה based on an innovative etymological observation (Hos 3:2)

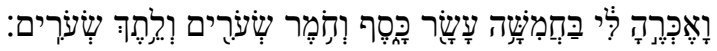

"And I bought her for myself for fifteen pieces of silver. And a homer of barley and a letekh of barley."

The exegetical difficulty in the above verse is introduced by the first word-waekreha-which throughout the Masoretic Text appears in this form on here. Rabbinic tradition sees in the term waekreha the verb כרה - kara, that is, "to purchase" ("I bought her for myself for fifteen pieces of silver. And a homer of barley and a letekh of barley"). ${ }^{23}$ Meanwhile, Yefet recognizes here the verb - -nakhar, i.e., "to know," as in the noun -hakara ("recognizing," "knowing"). Therefore, in his Arabic translation of this verse, Yefet has: "I will make her known to others as mine, for fifteen pieces of silver ..." Thus, according to Yefet, the point is not that the prophet bought the harlot for the stipulated price. It is rather that by giving people the money, the prophet — symbolically — made the people recognize her as his wife. This interpretation is congruent with Yefet's belief that the prophet did not write about his wife, but about the people of Israel.

\footnotetext{
${ }^{22}$ Yefet claims that the allusion to Elijah here is derived from rabbinic tradition. He refers to rabbinic commentators as khakhamim ("sages").

${ }^{23}$ See. M. Polliack, E. Schlossberg, Yefet ben 'Eli's Commentary on Hosea, 294, f.n. 2 .
} 
6. Translation with a presupposition of a potential Arab reader's knowledge (Hos 3:4)

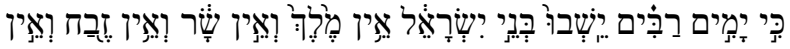

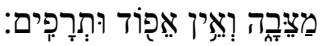

"For the children of Israel shall dwell many days without a king and without a prince and without a sacrifice and without a [sacred] pillar and without and efod and household idols [trafim]."

Yefet translates the above passage into Arabic in the following way:

"For a long time, the sons of Israel will be left without a king, and without a leader, and without a sacrifice, and without a monument, and without an efod, and without an astrolabe [astralab]."

The use of the Arabic word astralab ("astrolabe") here is significant, since among Jews the term trafim was commonly known as one of the elements of the priestly garment worn during divination. For that reason, Yefet did not have to translate the word into Arabic, but could instead leave it in its Hebrew original form, as he does on other occasions. ${ }^{24}$ However, if he decided to use the Arabic word astralab to render the term trafim, we may assume that what we are dealing with here is another instance when the Karaite exegete not only wished to be understood by Jews, but also wanted to address Muslim Arabs who would be reading his translation and commentary. Admittedly, astrolabe does not mean the exact same thing as the Hebrew trafim; nevertheless, Arabs knew what an astrolabe is, since Arab astrologers and astronomers used this instrument to determine the position of the Sun, the moon and the stars.

${ }^{24}$ For instance, he leaves the word goim untranslated in the Arabic text; see ibid., 172 . 


\section{Announcement of the future for Israel (Hos 6:2)}

In his exegesis Yefet more than other Karaite commentators resorts to images drawn from everyday life, a practice reminiscent of the rabbinic method, intended to elucidate and familiarize the reader with the realities presented in particular verses. A significant instance of the above can be found in Yefet's commentary on Hos 6:2:

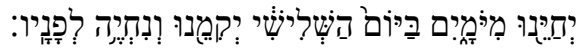

"He will restore us to life after two days, on the third day He will raise us up and we will live in His presence."

Yefet's Arabic translation looks as follows:

"He will heal us after two days, on the third day He will raise us and we will live in His presence."

Yefet justifies the rendering of the first word yekhayenu as "he will heal us" on the basis of Isa 38:9, where the verb khaya

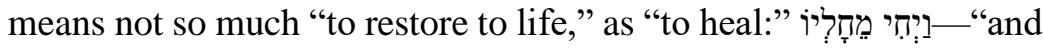
he was healed of his disease." However, one must note the continuation of the commentary, where Yefet makes a comparison to the behavior of a learned scholar, who on the first day of encountering his patient sets aside time for observation, in order to acquaint himself with the symptoms of the disease. It is only on the second day that he administers medications, and as a result, the disease leaves the patient, so that on the third day ill person is healed. Yefet then adds that in a similar manner, God brought various diseases upon Israel, until pagans concluded that the Israelites could not be healed. However, the Lord of the Universe, who hurled various ailments on His people, will also be the One who heals Israel much quicker, when He looks at them at the moment of their conversion. And whereas much like rabbinic commentators Yefet indicates here that this verse refers to the Jews' return from the exile, he is the only one to notice in the expression lefanav- "in front of His face / in His presence" a direct reference to the land of Israel. In 
that regard, Yefet, who spent the latter half of his life in Jerusalem, confirms the Jewish belief that the land of Israel has been given a special grace by God. As in the case of the prophet Jonah, who speaks of his own exile and the inability to see the temple in terms of remaining out of God's gaze (Jonah 2:5), Yefet considers "being before the face of God" to be a privilege enjoyed by those living in the Promised Land.

This short survey of selected exegetical issues drawn from Yefet ben Eli's Commentary on the Book of Hosea shows us that Karaism's point of exegetical point of departure, much like that of Protestantism, soon fell apart: It is impossible to read the Holy Scriptures without any interpretation, especially without the interpretative assistance of tradition, which the Karaites proved unable to liberate themselves from. Yefet ben Eli established his own exegetical tradition, later used by Karites who over the centuries would write their own commentaries. In spite of the polemic between the Karaite and the rabbinic movements, Karaites benefitted from rabbinic tradition, though more often than not - they did not admit it.

The apologetic aspect of Yefet's Commentary is significant. The willingness to reach Muslims through his work is a unique among Karaite exegetes, and it is a testament to Yefet's conviction that the "missionary" nature of the Karaite movement should have been carried out in a practical and accessible manner - at least language-wise.

Yefet ben Eli's observations, interpretations, and his profound knowledge of Hebrew are so exhaustive that it enabled him to draw innovative etymological conclusions about names, proper nouns, verbs, and Biblical symbolism. His aptitude and achievements in this regard deserve further research. Since both rabbinic exegesis and interpretation are valuable for the analysis of the Masoretic Text, there is no doubt that their expansion through recourse to Karaite exegesis will contribute to a better understanding of the Biblical text. 